\title{
STUDI PERENCANAAN PENGELOLAAN DAMPAK LINGKUNGAN BERKELANJUTAN PADA BANGUNAN JENIS CABIN HOTEL
}

\author{
Hapsari Wahyuningsih \\ Program Studi Arsitektur, Fakultas Sains dan Teknologi, Universitas 'Aisyiyah Yogyakarta, Jl. \\ Siliwangi (Ring Road Barat) No. 63 Mlangi, Nogotirto, Gamping, Sleman, Yogyakarta, 55292 \\ hapsariw@unisayogya.ac.id
}

Diterima: 29-10-2019_Direview : 06-04-2020Ｄirevisi: 16-05-2020_Disetujui: 17-05-2020

\begin{abstract}
ABSTRAK. Pengelolaan dampak lingkungan hidup dari bangunan hotel terutama jenis cabin hotel harus sesuai dengan kemampuan dan daya dukung lingkungan setempat. Penelitian ini bertujuan untuk mengetahui Perencanaan Pengelolaan Dampak Lingkungan Berkelanjutan yang sesuai dengan kemampuan dan daya dukung lingkungan sekitar terutama pada bangunan jenis Cabin Hotel. Variabel penelitian meliputi 2 (dua) parameter yaitu Parameter Besaran Skala Kegiatan dan Parameter Dampak Lingkungan Yang Ditimbulkan. Analisis yang digunakan pada penelitian kali ini adalah Analisis Kuantitatif dan Analisis Deskriptif Kualitatif. Hasil penelitian menunjukkan parameter besaran skala kegiatan adalah penggunaan lahan untuk bangunan dan parkir sebesar $48,53 \%$ dari total luas lahan, penggunaan air sebesar $4,8 \mathrm{~m} 3 / \mathrm{hr}$, sampah yang dihasilkan sebesar $28 \mathrm{Kg} / \mathrm{h}$, penggunaan energi listrik dengan daya 33 KVA dan Genset 44 KVA, jumlah tenaga kerja hotel 10 orang. Hasil analisis terhadap ketersediaan ruang parkir sangat tergantung dari jenis Hotel dan segmen pasar yang dituju, yaitu segmen tidak membawa kendaraan 'menginap' untuk Cabin Hotel ini. Kesimpulan dari hasil penelitian adalah Perencanaan Pengelolaan Dampak Lingkungan Berkelanjutan Pada Bangunan Jenis Cabin Hotel dipengaruhi oleh besaran skala kegiatan yang terdiri dari 9 indikator yaitu luasan bangunan, penggunaan air, penggunaan energi listrik dan bbm, jenis komoditas usaha, sampah yang ditimbulkan, jumlah tenaga kerja, jenis peralatan dan mesin, konservasi lahan hijau dan ketersediaan area parkir.
\end{abstract}

Kata kunci: Dampak Lingkungan; Lingkungan Berkelanjutan; Kabin Hotel

ABSTRACT. Management of the environmental impact of hotel buildings, especially the type of hotel cabin, must be following the environment's capabilities and carrying capacity. This study aims to find out Sustainable Environmental Impact Management Planning that is following the abilities and carrying capacity of the surrounding environment, especially in Cabin Hotel type buildings. Research Variables include two main parameters, Parameter (1) The Scale Of Activity and Parameter (2) The Environmental Impacts that are caused. The analysis used in this research is a quantitative analysis and qualitative descriptive analysis. The results showed that the scale of the activity was land use for buildings and parking at $48.53 \%$ of the total land area, water use at $4.8 \mathrm{m3} /$ day, waste generated at $28 \mathrm{~kg} /$ day, the use of electrical energy with $33 \mathrm{KVA}$ power and Genset $44 \mathrm{KVA}$, the number of hotel workers ten people. The analysis results of the availability of parking spaces are very dependent on the type of hotel and the target market segment. The conclusion from this research that the Planning for Sustainable Environmental Impact Management in the Hotel Cabin Type Building is influenced by the magnitude of the scale of activities consisting of 9 indicators namely the extent of the building, water use, the use of electricity and fuel, types of business commodities, waste generated, the amount of labor work, types of equipment and machinery, conservation of green land and the availability of parking areas.

Keywords: Environmental Impact; Sustainable Environment; Cabin Hotel

\section{PENDAHULUAN}

Hotel jenis Cabin atau Cabin Hotel menjadi jawaban atas tumbuhnya segmen wisatawan jenis pelancong "backpackers" di Kota Surakarta. Hal tersebut dapat dilihat dengan maraknya bermunculan Hotel dengan tipe Cabin hotel yang siap melayani wisatawan jenis pelancong "backpakers" dengan harga yang relatif terjangkau dengan pelayanan yang optimal layaknya hotel bintang. Hotel jenis ini bisa dikategorikan sebagai bentuk baru dari hotel transit dimana tamu yang singgah tidak lama karena tujuan tertentu dari tamu baik itu berbisnis maupun bagian dari perjalanan besar dari tamu tersebut. Berdasarkan jenis tamu 
dan lama tamu menginap, Hotel Transit /transient hotel adalah tempat yang dirancang untuk persinggahan sementara dari orangorang yang melakukan perjalan, dimana tamu menginap selama satu atau dua malam (Krestanto, 2019).

Sebagai salah satu upaya dalam menciptakan lingkungan hidup perkotaan yang berkelanjutan maka pengelolaan dampak lingkungan yang akan ditimbulkan dari operasional bangunan hotel harus ramah lingkungan dan seminimal mungkin berdampak negatif terhadap lingkungan hidup sekitar hotel itu sendiri, dengan kata lain pengelolaan dampak lingkungan hidup dari bangunan hotel terutama jenis cabin hotel harus sesuai dengan kemampuan dan daya dukung lingkungan setempat. Upaya pengelolaan lingkungan dan upaya pemantauan lingkungan terjadi di seluruh sektor salah satunya pariwisata yaitu bangunan hotel. Kecenderungan pemanfaatan secara maksimal sebagai area pendukung usaha akomodasi menjadikan terbatasnya kesediaan ruang terbuka (Sega, 2015)

Mendasarkan pada kenyataan tersebut, maka diperlukan sebuah perencanaan pengelolaan lingkungan hidup yang berkelanjutan dari sebuah hotel yaitu Cabin Hotel.

Hotel menurut Keputusan Menteri Parpostel no Km 94/HK103/MPPT 1987 tentang Ketentuan Usaha dan Penggolongan Hotel, adalah salah satu jenis akomodasi yang mempergunakan sebagian atau keseluruhan bagian untuk jasa pelayanan penginapan, penyedia makanan dan minuman serta jasa lainnya bagi masyarakat umum yang dikelola secara komersil. Sedangkan pengertian hotel menurut Endar \& Sulartiningrum (1996:8) adalah Bangunan yang dikelola secara komersil dengan memberikan fasilitas penginapan untuk masyarakat umum dengan fasilitas sebagai berikut :

1) Jasa penginapan

2) Pelayanan makanan dan minuman

3) Pelayanan barang bawaan

4) Pencucian pakaian

5) Penggunaan fasilitas perabot dan hiasan hiasan yang ada di dalamnya.

Menurut Lawson (1976) Hotel merupakan sarana tempat tinggal umum untuk wisatawan dengan memberikan pelayanan jasa kamar, penyedia makanan dan minuman serta akomodasi dengan syarat pembayaran.
Pada umumnya, Analisis tahap prakonstruksi, analisis tahap konstruksi dan analisis tahap pascakonstruksi adalah analisis dari keseluruhan upaya pengelolaan lingkungan dan upaya pemantauan lingkungan (Samah \& Rahma, 2019). Penelitian kali ini ditekankan pada upaya pengelolaan lingkungan berkelajutan dari Cabin Hotel terutama pada tahap pascakonstruksi yaitu tahap operasional hotel.

Variabel yang akan diteliti meliputi 2 Variabel Utama yaitu Variabel Besaran Skala Kegiatan dan Variabel Dampak Lingkungan yang ditimbulkan. Tiap Variabel terdiri dari beberapa indikator yang telah ditetapkan.

Rumusan masalah dari penelitian ini adalah Bagaimana Perencanaan Pengelolaan Dampak Lingkungan Berkelanjutan Pada Bangunan Jenis Cabin Hotel.

Tujuan Penelitian ini adalah untuk mengetahui Perencanaan Pengelolaan Dampak Lingkungan Hidup Berkelanjutan pada Bangunan Jenis Cabin Hotel, khususnya pada Front One Cabin Hotel di Surakarta.

Diharapkan hasil penelitian ini dapat memberikan manfaat bagi:

1. Pemangku Kebijakan terkait seperti Dinas Lingkungan Hidup, Dinas Kesehatan dan Dinas Pariwisata terutama terkait dengan pengelolaan dampak lingkungan sebuah bangunan komersial berupa Cabin Hotel.

2. Pemrakarsa/pemilik maupun pengelola bangunan jenis Cabin Hotel dalam upaya pengelolaan dampak lingkungan hidup yang berkelanjutan

3. Hasil penelitian ini diharapkan dapat menjadi salah satu referensi yang dapat digunakan sebagai dasar Pemangku Kebijakan untuk mengambil keputusan dalam pemberian ijin lingkungan khususnya Front One Cabin Hotel Surakarta untuk beroperasional.

\section{KERANGKA KONSEP}

Kerangka konsep pada Penelitian dengan judul Studi Perencanaan Pengelolaan Dampak Lingkungan Hidup Berkelanjutan pada Bangunan Jenis Cabin Hotel diturunkan dari Keputusan Menteri Lingkungan Hidup (2002) Nomor : 86 tahun 2002 tentang Pedoman Pelaksanaan Upaya Pengelolaan Lingkungan Hidup Dan Upaya Pemantauan Lingkungan Hidup yang menyatakan bahwa perlu diuraikan secara jelas dan singkat tentang dampak lingkungan yang mungkin terjadi yaitu tentang kegiatan yang menjadi sumber dampak 
terhadap lingkungan, jenis dampak lingkungan yang terjadi, ukuran yang menyatakan besaran dampak dan hal-hal lain yang perlu disampaikan untuk menjelaskan dampak lingkungan yang akan terjadi terhadap lingkungan hidup.

Upaya pelestarian lingkungan hidup dilakukan dengan meminimalkan perubahan kondisi awal dari tapak, menggunakan material bangunan yang renewable, reuse, recycle dan rendah kandungan energi, serta memperhitungkan limbah cair dan limbah padat dan pengolahannya (Karyono, 2010)

Kerangka Konsep penelitian juga menggunakan Panduan Pengembangan Air Minum menurut Direktorat Pengembangan Air Minum, Ditjen Cipta Karya Departemen Pekerjaan Umum tahun 2006, Peraturan Menteri Lingkungan Hidup No. 12 tahun 2009 tentang Pemanfaatan Air Hujan, Peraturan Menteri Pekerjaan Umum No. 5/PRT/M/2008 tentang Pedoman Penyediaan dan Pemanfaatan Ruang Terbuka Hijau Di Kawasan Perkotaan, Undang-Undang Republik Indonesia No.18 tahun 2018 tentang Pengelolaan Sampah dan Analisa Kebutuhan Ruang Parkir.

Analisis Kuantitatif Terhadap Variabel Besaran Skala Kegiatan dijelaskan pada tabel berikut :

Tabel 1. Tabel Metode Analisis Kuantitatif Variabel Penelitian

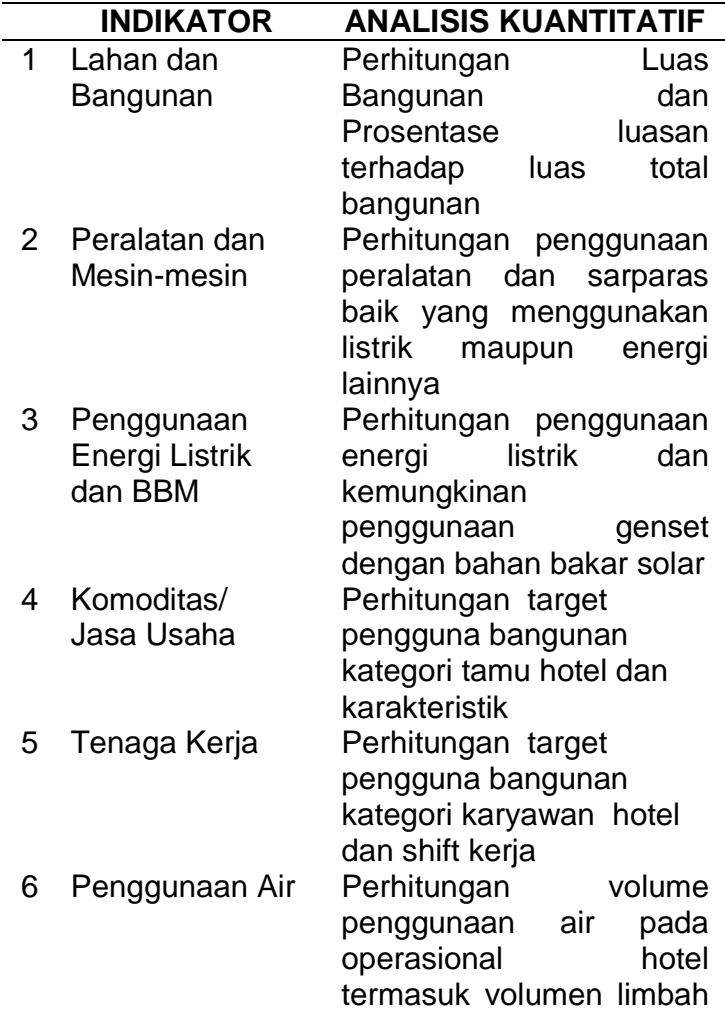

\begin{tabular}{|c|c|c|}
\hline & INDIKATOR & ANALISIS KUANTITATIF \\
\hline \multirow[b]{2}{*}{7} & & cair yang dihasilkan \\
\hline & San & $\begin{array}{l}\text { Perhitungan volume } \\
\text { sampah yang dihasilkan } \\
\text { pada dari operasional } \\
\text { hotel hingga } \\
\text { kemungkinan limbah B3 }\end{array}$ \\
\hline 8 & $\begin{array}{l}\text { Program } \\
\text { Konservasi Air } \\
\text { dan } \\
\text { Pengembangan } \\
\text { Ruang Hijau }\end{array}$ & $\begin{array}{l}\text { Perhitungan } \\
\text { perencanaan konservasi } \\
\text { air dan perencanaan } \\
\text { ruang terbuka hijau pada } \\
\text { bangunan sesuai dengan } \\
\text { peraturan yang berlaku }\end{array}$ \\
\hline 9 & $\begin{array}{l}\text { Analisis } \\
\text { Kebutuhan } \\
\text { Parkir }\end{array}$ & $\begin{array}{l}\text { Perhitungan kebutuhan } \\
\text { parkir pada saat } \\
\text { operasinal hotel }\end{array}$ \\
\hline
\end{tabular}

Sumber : Analisis Peneliti diadopsi dari KepMen LH Nomor : 86 /2002 tentang Pedoman Pelaksanaan Upaya Pengelolaan Lingkungan Hidup Dan Upaya Pemantauan Lingkungan Hidup, 2019

Analisis deskriptif Kualitatif Terhadap Variabel Dampak Lingkungan Yang Ditimbulkan dijelaskan pada tabel berikut ini :

\begin{tabular}{|c|c|c|}
\hline NO & INDIKATOR & $\begin{array}{l}\text { ANALISIS } \\
\text { DESKRIPTIF } \\
\text { KUALITATIF }\end{array}$ \\
\hline 1 & $\begin{array}{l}\text { Penurunan kualitas } \\
\text { udara (debu) dan } \\
\text { peningkatan } \\
\text { gangguan } \\
\text { kebisingan }\end{array}$ & $\begin{array}{l}\text { Analisis Desktiptif } \\
\text { Kualitatif pada tiap } \\
\text { indikator meliputi } \\
\text { beberapa aspek } \\
\text { sebagai berikut: }\end{array}$ \\
\hline 2 & $\begin{array}{l}\text { Penurunan Kualitas } \\
\text { Air Permukaan }\end{array}$ & $\begin{array}{l}\text { a. Komponen } \\
\text { lingkungan yang }\end{array}$ \\
\hline 3 & $\begin{array}{l}\text { Penurunan } \\
\text { Kuantitas Air \& } \\
\text { Peningkatan Air } \\
\text { Larian (run off) }\end{array}$ & $\begin{array}{l}\text { terkena dampak } \\
\text { b. Sumber dampak } \\
\text { c. Jenis dampak } \\
\text { d. Besaran dampak }\end{array}$ \\
\hline 4 & Timbunan Sampah & \\
\hline 5 & Bahaya Kebakaran & \\
\hline 6 & $\begin{array}{l}\text { Gangguan Lalu } \\
\text { Lintas }\end{array}$ & \\
\hline 7 & $\begin{array}{l}\text { Kesempatan Kerja } \\
\text { dan Berusaha }\end{array}$ & \\
\hline 8 & $\begin{array}{l}\text { Keamanan dan } \\
\text { Kenyamanan } \\
\text { Lingkungan }\end{array}$ & \\
\hline \multicolumn{3}{|c|}{$\begin{array}{l}\text { Sumber : Analisis Peneliti diadopsi dari KepMen LH } \\
\text { Nomor : } 86 \text { /2002 tentang Pedoman Pelaksanaan } \\
\text { Upaya Pengelolaan Lingkungan Hidup Dan Upaya } \\
\text { Pemantauan Lingkungan Hidup, } 2019\end{array}$} \\
\hline
\end{tabular}

\section{METODE PENELITIAN}

Variabel penelitian dengan judul Perencanaan Pengelolaan Dampak Lingkungan Berkelanjutan Pada Bangunan Jenis Cabin Hotel kali ini terdiri dari Parameter dan Indikator yang telah ditentukan berdasarkan pada kajian pustaka yang dilakukan.

Paramater Besaran skala kegiatan terdiri dari 9 indikator yaitu Lahan dan bangunan, 
peralatan dan mesin-mesin, penggunaan energi listrik dan BBM, Komoditas/jasa usaha, tenaga kerja, penggunaan air, sampah, Program Konservasi Air dan Pengembangan Ruang Hijau, Analisis kebutuhan parkir.

Parameter Dampak Lingkungan yang Ditimbulkan terdiri dari Penurunan kualitas udara (debu) dan peningkatan gangguan kebisingan, penurunan kualitas air permukaan, penurunan kuantitas air dan peningkatan air larian(run off), timbunan sampah, bahaya kebakaran, gangguan lalu lintas, kesempatan kerja dan berusaha, keamanan dan kenyamanan lingkungan.

Kegiatan pengumpulan data terbagi menjadi 2 yaitu pengumpulan data primer dan pengumpulan data sekunder. Pengumpulan data primer dilakukan dengan (1) Survei Lapangan, Panduan Survei Lapangan meliputi Lahan dan Bangunan yaitu Batas-batas lahan, kondisi sekitar lahan, eksisting area parkir, eksisting ruang terbuka serta rencana penempatan peralatan mesin, (2) Wawancara, dilakukan terhadap pemrakarsa dan Kontraktor pembangunan Cabin Hotel. Wawancara terhadap pemrakarsa dilakukan untuk mengetahui perencanaan operasinal Cabin Hotel ketika sudah terbangun. Panduan Wawancara meliputi aspek target konsumen, rencana jumlah kamar, rencana jenis- fasilitas yang disediakan, rencana jumlah karyawan, rencana penggunaan energi listrik dan BBM serta untuk menggali kemungkinankemungkinan permasalahan yang dapat timbul pada waktu operasional hotel nantinya. Wawancara dengan pihak Kontraktor pembangunan Cabin Hotel dilakukan untuk mengetahui penjelasan lebih lanjut dari Detail Engineering Design (DED) dari perencanaan pembangunan Cabin Hotel tersebut (DED Cabin Hotel Hellow Cow Front One, Surakarta, 2019).

Pengumpulan data sekunder dilakukan dengan (1) Kajian Pustaka (Survei litaretur) (2) Kajian DED (Detail Engineering Design). Metode ini adalah pengumpulan data yang dilakukan dengan mengkaji Detail Enginering Design dari Cabin Hotel untuk memperoleh gambaran lengkap perencanaan pambangunan Cabin Hotel terutama terkait dengan Luasan Lahan Dan Bangunan, Rencana Konstruksi, Rencana Arsitektural, Rencana Pemipaan, Rencana Listrik, Rencana Drainase, Rencana Saluran Air Hujan , dan lain-lain terkait dengan desain Cabin Hotel.
HASIL DAN PEMBAHASAN

Parameter Besaran Skala Kegiatan

a. Indikator Lahan dan Bangunan

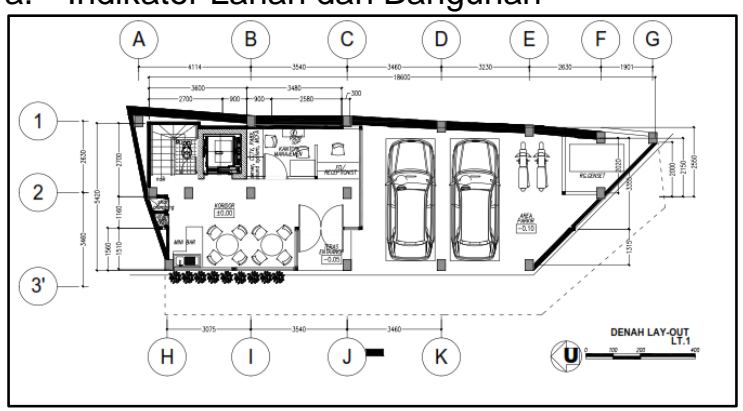

Gambar 1. Denah Lantai 1 Cabin Hotel Hellow Cow Front One Surakarta (Sumber : DED Hotel, 2019)

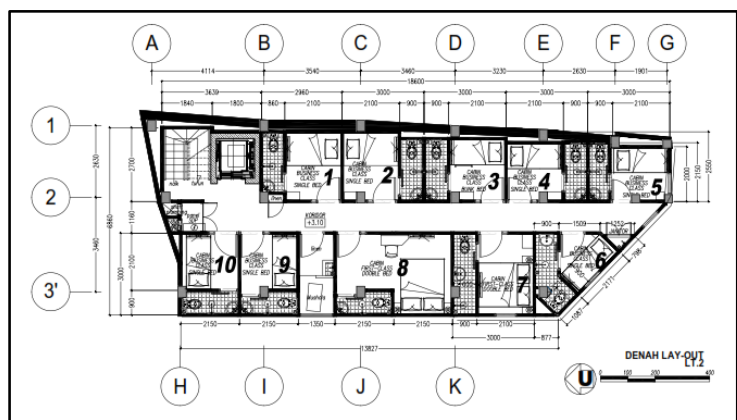

Gambar 2. Denah Lantai 2 Cabin Hotel Hellow Cow Front One Surakarta (Sumber : DED Hotel, 2019)

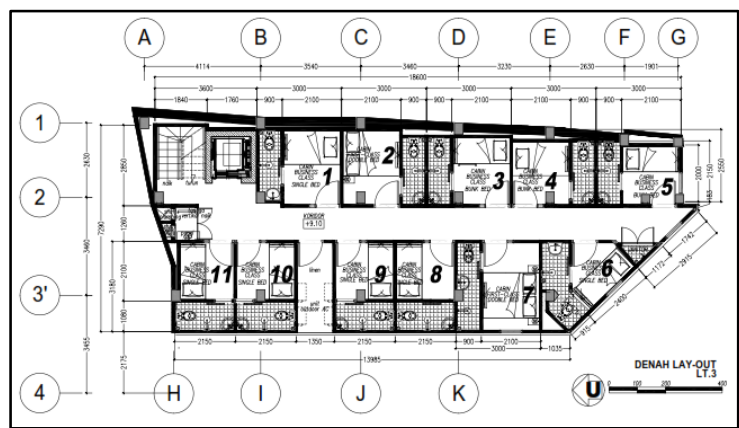

Gambar 3. Denah Lantai 3 Cabin Hotel Hellow Cow Front One Surakarta (Sumber : DED Hotel, 2019)

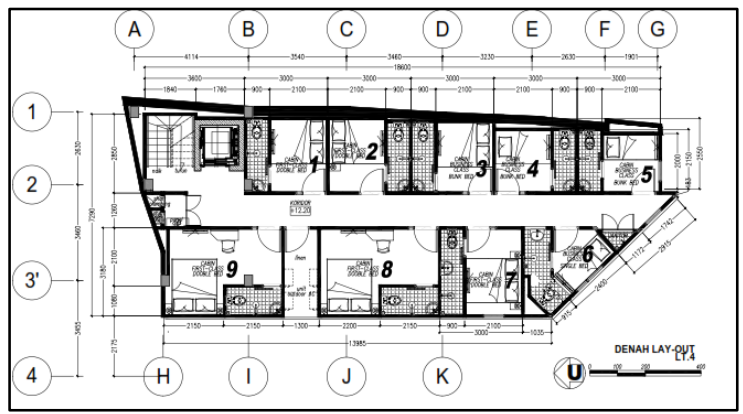

Gambar 4. Denah Lantai 4 Cabin Hotel Hellow Cow Front One Surakarta (Sumber : DED Hotel, 2019)

Tabel 3. Penggunaan lahan dan prosentasenya terhadap luas lahan 


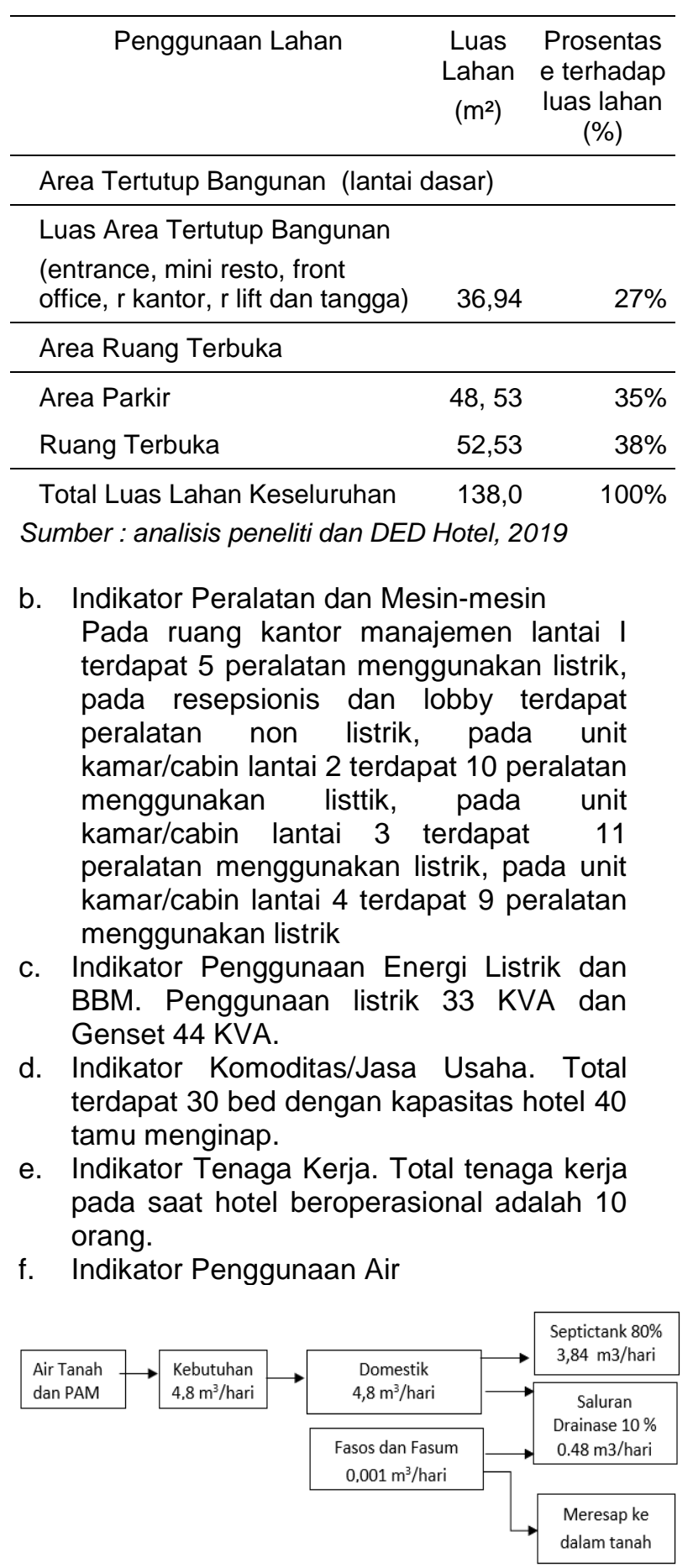

Gambar 5. Neraca penggunaan air (sumber : analisis penelitir 2019 dan DED hotel)

g. Indikator Sampah. Analisa perhitungan sampah yang dihasilkan hotel per hari adalah $28 \mathrm{~kg} /$ hari,

h. Indikator Program Konservasi Air dan Pengembangan Ruang Hijau. Sesuai dengan ketentuan Permen LH No. 12 /2009 tentang pemanfaatan air hujan, sehingga jumlah sumur resapan dangkal adalah 1 unit dan Lubang resapan biopori (LRB) adalah 2 unit. Penggunaan LRB sebagai pencegahan dan meminimalkan terjadinya bencana banjir (Hilwatullisan, 2011)

i. Indikator Kebutuhan Parkir. Analisa kebutuhan parkir dilakukan dengan menghitung kebutuhan parkir untuk karyawan. Kebutuhan parkir untuk tamu tidak disertakan dengan asumsi menyesuaikan karakteristik tamu hotel seperti yang telah dijelaskan. Pemisahan tempat parkir antara pengunjung dengan karyawan dilakukan oleh pihak manajemen dikarenakan durasi parkir karyawan lebih lama daripada pengunjung (Krestanto, 2019). Kebutuhan parkir kali ini dihitung dari jumlah karyawan yang datang bekerja/harinya, yaitu 1 orang tiap divisi yaitu 1 orang GM, 1 orang administrasi, 1 orang resepsionis, 1 orang waiter, 1 orang Housekeeping dan 1 orang security. Sehingga diasumsikan membutuhkan parkir sepeda motor sebanyak 5 sd 6 satuan ruang parkir untuk sepeda motor dan 1 satuan ruang parkir untuk mobil.

\section{Indikator Dampak Lingkungan yang Ditimbulkan}

a. Penurunan kualitas udara (debu) dan peningkatan gangguan kebisingan.

Sumber dampak ditimbulkan dari kegiatan mobilisasi kendaraan yang keluar masuk /dropping di lokasi cabin hotel. Jenis dampak yang terjadi adalah penurunan kulitas udara (debu) dan peningkatan kebisingan. Besaran dampak sebesar area lingkup kegiatan hotel dan lingkungan sekitarnya

\section{b. Penurunan Kualitas Air Permukaan}

Sumber dampak ditimbulkan dari kegiatan operasional cabin hotel yaitu penggunaan air untuk kegiatan domestik penghuni cabin hotel (tamu dan karyawan) serta air untuk penyiraman tanaman. Jenis Dampak yang terjadi adalah penurunan kualitas air permukaan yang diakibatkan oleh buangan limbah cair domestik. Peningkatan limbah cair salah satunya disebabkan oleh peningkatan jumlah hotel yang apabila tidak ditanggulangi secara tepat maka berdampak pada manusia dan makhluk hidup lainnya sehingga limbah cair hotel yang tidak diolah akan berpengaruh besar terhadap pencemaran lingkungan (Sitompul et al., 2013). Untuk itu dilakukan perhitungan terhadap limbah cair yang ditimbulkan dari bangunan hotel cabin ini. Besaran dampak sebesar total area tertutup bangunan dan area parkir sebesar 48,53\% dari total luas lahan keseluruhan. Limbah cair yang ditimbulkan sebesar 4,33 m3/hari keseptiktank dan 0,48 m3/hari ke saluran 
drainase (IPAL) kota serta jumlah sumur resapan dangkal 1 dan lubang biopori 2 .

\section{c. Penurunan Kuantitas Air \& Peningkatan Air Larian (run off)}

Sumber dampak ditimbulkan dari penggunaan air untuk kegiatan operasional Cabin Hotel dan penutupan sebagian lahan oleh bahan kedap air berupa bangunan dan jalan. Jenis Dampak yang terjadi adalah terjadinya penurunan kuantitas air tanah, dan peningkatan air larian. Besaran dampak sebesar penggunaan air \pm $4,8 \mathrm{~m} 3 / \mathrm{hr}$, lahan tertutup bangunan seluas sebesar $27 \%$ dari total luas lahan dan sebagai area parkir seluas $35 \%$.

\section{d. Timbunan Sampah}

Sumber dampak yang ditimbulkan dari sampah yang dihasilkan dari kegiatan operasional Cabin Hotel, yaitu sampah yang dihasilkan dari kegiatan/aktivitas tamu hotel dan karyawan, serta banyaknya sampah yang terkumpul di TPS Cabin Hotel yang belum dikelola oleh petugas sampah setempat serta sampah alamiah (daun kering, tanaman kering).

\section{Besaran sampah yang ditimbulkan} menggunakan satuan per orang per hari jika sampah bersumber dari kantor, sekolah dan toko), sedangkan menggunakan satuan panjang per hari jika sampah bersumber dari jalan, dan menggunakan satuan per kamar per hari jika sampah berasal dari hotel (Di et al., 2017). Pada penelitian kali ini, timbunan sampah diakumulasi dari jumlah karyawan dan tamu hotel dengan asumsi pada saat operasional hotel.

Jenis Dampak yang terjadi adalah penumpukan sampah yang dihasilkan dari operasional cabin Hotel baik sampah organik maupun anorganik. Penurunan nilai estetika lingkungan akibat dari penimbunan sampah serta bau yang ditimbulkan dari sekitar tempat sampah. Besaran dampak sebesar jumlah sampah yang dihasilkan pada kegiatan operasional $\pm 28 \mathrm{Kg} / \mathrm{hr}$.

\section{e. Bahaya Kebakaran}

Dilihat dari potensi kebakaran, maka materialmaterial di hotel seperti tabung gas, sprei, karpet dan lainnya merupakan material mudah terbakar sehingga hotel dikategorikan sebagai bangunan dengan bahaya kebakaran ringan (Kowara, 2017). Sumber dampak ditimbulkan dari operasional kegiatan/aktivitas cabin hotel ini adalah yang dapat menimbulkan percikan api misalnya terjadi konsleting sambungan ketika menghidupkan saklar, dan berdekatan dengan kertas yang mudah terbakar serta Terkena musibah sambaran petir. Jenis Dampak yang terjadi adalah terjadinya bahaya kebakaran. Besaran dampak sebesar penggunaan energi listrik dengan daya 33 KVA dan Genset 44 KVA.

\section{f. Gangguan Lalu Lintas}

Sumber dampak ditimbulkan dari kegiatan mobilisasi kendaraan karyawan cabin hotel maupun kendaraan tamu cabin hotel meskipun calon pengguna /tamu adalah tipe tanpa kendaraan 'menginap'. Jenis Dampak yang terjadi adalah gangguan lalu lintas. Besaran dampak meliputi gang / jalan kampung yang berada disekitar lokasi kegiatan

\section{g. Kesempatan Kerja dan Berusaha}

Untuk memberdayakan masyarakat sekitar hotel dan sebagai sarana pengasah softskill masyarakat sekitar maka diperlukan suatu tanggung jawab sosial perusahaan yaitu CSR. (Suhardjanto et al., 2018).

Sumber dampak ditimbulkan dari penerimaan tenaga kerja Cabin Hotel khususnya dari masyarakat sekitar yang berdasarkan kualifikasinya dan terbukanya peluang usaha untuk menambah tingkat perekonomian masyarakat sekitar. Jenis Dampak yang terjadi adalah terciptanya kesempatan kerja sebagai penjaga keamanan atau sebagai tenaga kebersihan sesuai skill yang dibutuhkan dan terbukanya peluang usaha bagi masyarakat sekitar lokais cabin Hotel. Besaran dampak meliputi lingkungan masyarakat sekitar lokasi Cabin Hotel dengan peluang jumlah tenaga kerja yang dibutuhkan adalah \pm 10 orang.

\section{Keamanan dan Kenyamanan Lingkungan}

Sumber dampak yang ditimbulkan dari mulai dioperasikannya Cabin Hotel serta kegiatan/aktivitas di dalam bangunan cabin hotel. Jenis Dampak yang terjadi adalah timbulnya gangguan keamanan dan kenyamanan didalam area Cabin Hotel dan lingkungan sekitarnya. Besaran dampak meliputi area Cabin Hotel dan lingkungan masyarakat sekitar cabin hotel

Pembahasan penelitian adalah sebagai berikut:

a. Penurunan kualitas udara (debu) dan peningkatan gangguan kebisingan

Upaya pengelolaan lingkungan yang dilakukan yaitu memperbanyak tanaman penghijauan terutama yang menyerap polusi udara. Apabila lahan yang digunakan mempunyai luasan yang sempit, bisa menggunakan tanaman 
didalam pot atau tanaman pergola. Selain itu dilakukan penyiraman dengan air pada aeral yang diperkirakan berdebu (misalnya area jalan masuk keluar kendaraan, area parkir, dll), serta memberikan dinding pembatas area lingkup kegiatan dengan lingkungan sekitar, untuk meminimalisir gangguan yang ditimbulkan dari dalam oleh kegiatan operasional Cabin Hotel, dan yang terakir adalah memperhatikan jam kegiatan operasionalnya

Upaya pemantauan lingkungan yang dilakukan yaitu memantau jumlah tanaman penghijauan yang ditanam fan memberikan tanggapan ataupun keluhan dari penghuni Cabin Hotel dan masyarakat sekitarnya

\section{b. Penurunan Kualitas Air Permukaan}

Upaya pengelolaan lingkungan yang dilakukan yaitu mengalirkan limbah cair dari WC/closet (black water) ke septictank serta memelihara saluran drainase dari tumpukan sampah.

Upaya pemantauan lingkungan yang dilakukan yaitu memantau saluran drainase apakah berfungsi dengan baik atau tidak.

\section{c. Penurunan Kuantitas Air \& Peningkatan Air Larian (run off)}

Upaya pengelolaan lingkungan yang dilakukan yaitu menggunakan air secara efisien dan membuat saluran drainase berupa selokan pembuangan air kotor atau air hujan yang di usahakan menuju saluran pembuangan wilayah setempat atau saluran kota, supaya tidak ada genangan air kotor maupun air hujan.

Upaya pemantauan lingkungan yang dilakukan yaitu memantau ada tidaknya genangan / banjir yang terjadi pada waktu hujan

\section{d. Timbunan Sampah}

Upaya pengelolaan lingkungan yang dilakukan yaitu menyediakan tempat sampah terpilah, tertutup serta kedap air, dan dibuat terpilah sesuai pemilahan sampah, antara sampah organik dengan sampah anorganik di dalam maupun diluar area lingkup kegiatan. Serta menjaga kebersihan lingkungan seluruh area kegiatan Cabin Hotel. Selain itu juga dilakukan kerjasama dengan pihak ketiga setempat / pihak kelurahan dalam pengelolaan limbah sampahnya dan melakukan pengelolaan sampah sesuai dengan peraturan daerah yang berlaku tentang pengelolaan sampah.

Upaya pemantauan lingkungan yang dilakukan yaitu memantau kebersihan dan estetika lingkungan secara visual.

\section{e. Bahaya Kebakaran}

Upaya pengelolaan lingkungan yang dilakukan yaitu mengontrol berkala kualitas kabel listrik, sambungan-sambungan kabel dan kemungkinannya bila terjadi konsleting/arus pendek. Memastikan adanya adanya ventilasi pada ruang-ruangnya serta menyediakan dan meletakkan APAR di tempat yang terlihat dan mudah dijangkau dan kontrol secara rutin terhadap APAR. Serta memasang papan peringatan "DILARANG MEROKOK" dan tanda peringatan lainnya yang dapat mencegah timbulnya bahaya kebakaran. Didukung pula dengan pemasangan arde (penangkal petir). Menempatkan barnagbarang yang mudah terbakar untuk jauh dari sumber panas mesin atau jauh dari sumber nyala api dan memasang alat tanda bahaya (alarm / system komunikasi yang selalu siap) juga merupakan upaya pengelolaan lingkungan yang dilakukan. Upaya pemantauan lingkungan yang dilakukan adalah melakukan pengamatan terhadap kondisi APAR dan kondisi instalasi listrik.

\section{f. Gangguan Lalu Lintas}

Upaya pengelolaan lingkungan yang dilakukan adalah menyediakan petugas keamanan (security) yang berfungsi juga untuk mengatur parkir kendaraan yang keluar masuk ke lokasi kegiatan pada area parkir. Upaya pemantauan lingkungan yang dilakukan adalah memantau kelancaran lalulintas disekitar area Cabin Hotel.

\section{g. Kesempatan Kerja dan Berusaha}

Upaya pengelolaan lingkungan sebagai perwujudan CSR yang dilakukan adalah mengutamakan warga sekitar sebagai tenaga kerja operasional Cabin Hotel, serta bekerjasama dengan RT dan Kelurahan setempat dalam pengumuman kebutuhan tenaga kerja yang berdasarkan kualifikasinya Upaya pemantauan lingkungan yang dilakukan adalah memantau jumlah masyarakat sekitar yang menjadi tenaga kerja operasional Cabin Hotel

h. Keamanan dan Kenyamanan Lingkungan Upaya pengelolaan lingkungan yang dilakukan adalah memberikan tanda peringatan / tanda larangan yang dapat mencegah tindak kejahatan, serta memasang alat keamanan yang berupa CCTV pada tempat yang mudah dilihat semua kegiatan / aktivitas pada area Cabin Hotel. Selian itu pihak Hotel juga menjaga hubungan dan komunikasi yang baik antara pemilik, tamu hotel dengan warga sekitarnya dan ikut berpartisipasi dalam perayaan atau kegiatan yang dilaksanakan 
oleh lingkup RT dan kelurahan setempat serta memberikan bantuan-bantuan apabila dibutuhkan. Upaya pemantauan lingkungan yang dilakukan yaitu memantau tanggapan masyarakat terhadap kegiatan operasional Cabin Hotel tersebut

\section{KESIMPULAN}

Berdasarkan pada hasil analisis dan pembahasan, maka dapat disimpulkan beberapa hal. Perencanaan Pengelolaan Dampak Lingkungan Berkelanjutan Pada Bangunan Jenis Cabin Hotel dipengaruhi oleh beberapa faktor terkait yang berdampak pada penurunan kualitas udara, penurunan kualitas air permukaan, penurunan kuantitas air, timbunan sampah, bahaya kebakaran, gangguan lalu lintas, kesempatan kerja dan berusaha serta keamana dan kenyamanan lingkungan.

Perbedaan yang mendasar pada pengelolaan dampak lingkungan berkelanjutan pada bangunan jenis Cabin Hotel bila dibandingkan bangunan hotel jenis lainnya terletak pada area ruang parkir yang dibutuhkan karena perbedaan segmen pasar yang datang pada Cabin Hotel ini.

Secara lebih jelas, bahwa segmen pasar pada cabin hotel ini adalah tidak menggunakan kendaraan yang menginap di lokasi hotel, sehingga kebutuhan ruang parkir adalah minim. Beberapa faktor yang mempengaruhi perencanaan pengelolaan dampak lingkungan berkelanjutan pada bangunan jenis cabin hotel adalah sebagai berikut :

1) Luasan penggunaan lahan yang digunakan untuk bangunan Cabin Hotel

2) Penggunaan air oleh penghuni Cabin Hotel

3) Penggunaan energi listrik dan BBM yang digunakan oleh bangunan Cabin Hotel

4) Jumlah peralatan dan mesin yang digunakan oleh Cabin Hotel

5) Komoditas usaha/jasa yaitu jumlah kamar pada cabin hotel

6) Timbunan sampah yang ditimbulkan oleh penggunaan bangunan Cabin Hotel

7) Area ruang parkir yang dibutuhkan oleh bangunan Cabin Hotel

8) Konservasi hijau yang dilakukan oleh bangunan Cabin Hotel

9) Tenaga kerja yang dibutuhkan oleh Cabin Hotel

\section{DAFTAR PUSTAKA}

DED Cabin Hotel Hellow Cow Front One, Surakarta. (2019).
Di, P., Kabupaten, W., \& Progo, K. (2017). ANALISIS TIMBULAN DAN KOMPOSISI SAMPAH NON.

Endar, S., \& Sulartiningrum, S. (1996). Pengantar Industri Akomodasi dan Restoran. Gramedia Pustaka Utama.

Hilwatullisan. (2011). Lubang Resapan Biopori (Lrb) Pengertian Dan Cara Membuatnya Di Lingkungan Kita. Media Teknik, Vol. 8(No. 2), Hal. 1-11.

Karyono, T. H. (2010). No Title. In Green architecture; pengantar pemahaman arsitektur hijau di Indonesia. Jakarta: Rajawali Pers.

Keputusan Menteri Lingkungan Hidup Nomor: 86 /2002 tentang Pedoman Pelaksanaan Upaya Pengelolaan Lingkungan Hidup Dan Upaya Pemantauan Lingkungan Hidup, (2002).

Keputusan Menteri Parpostel no Km 94/HK103/MPPT 1987 tentang Ketentuan Usaha dan Penggolongan Hotel.

Kowara, R. A. (2017). Analisis Sistem Proteksi Kebakaran Sebagai Upaya Pencegahan Dan Penanggulangan Kebakaran. Jurnal Manajemen Kesehatan Yayasan RS.Dr. Soetomo, 3(1), 69. https://doi.org/10.29241/jmk.v3i1.90

Krestanto, H. (2019). Strategi Dan Usaha Reservasi Untuk Meningkatkan Tingkat Hunian Di Grand Orchid Hotel Yogyakarta. Jurnal Media Wisata, 17(1), 1-8.

Lawson. (1976). Hotels, Motels, and Condominius: Design, Planning and Maintenance. Architectural Press.

Samah, S., \& Rahma, P. D. (2019). Analisis Upaya Pengelolaan Lingkungan Dan Upaya Pemantauan Lingkungan (Studi Kasus: Rencana Pembangunan Gedung Inkubator Bisnis Universitas Tribhuwana Tunggadewi Malang). 3(2), 213-219. http://garuda.ristekbrin.go.id/documents/d etail/1466136

Sega, I. Y. S. (2015). Peran Upaya Pengelolaan Lingkungan Hidup.

Sitompul, D. F., Sutisna, M., \& Pharmawati, K. (2013). Pengolahan Limbah Cair Hotel Aston Braga City Walk dengan Proses Fitoremediasi menggunakan Tumbuhan Eceng Gondok. Jurnal Institut Teknologi Nasional, 1(2), 1-10.

Suhardjanto, D., Studi, P., Penyuluhan, S., \& Pemberdayaan, P. (2018). Existing Program Tanggung Jawab Sosial (Csr) Hotel Berbintang Terhadap Masyarakat Di Kota Surakarta. 3, 978-979. 